DOI: $10.1515 /$ pts-2017-0009

\title{
FEATURES OF SYNCHRONOUS ELECTRONICALLY COMMUTATED MOTORS IN SERVOMOTOR OPERATION MODES
}

\author{
J. Dirba, L. Lavrinovicha, R. Dobriyan \\ Riga Technical University, \\ 12/1 Azenes Str., Riga, LV-1048, LATVIA \\ e-mail: janis.dirba@rtu.lv
}

\begin{abstract}
The authors consider the features and operation specifics of the synchronous permanent magnet motors and the synchronous reluctance motors with electronic commutation in servomotor operation modes. Calculation results show that mechanical and control characteristics of studied motors are close to a linear shape. The studied motor control is proposed to implement similar to phase control of induction servomotor; it means that angle $\theta$ (angle between vectors of the supply voltage and non-load electromotive force) or angle $\varepsilon$ (angle between rotor direct axis and armature magnetomotive force axis) is changed. The analysis results show that synchronous electronically commutated motors could be used as servomotors.
\end{abstract}

Keywords: servomotor, synchronous reluctance motor, synchronous permanent-magnet motor.

\section{INTRODUCTION}

Servomotors are widely used in many devices and systems, for example, robotic systems, surveillance systems, automatic control systems, gyroscopic devices and others. Considering specific conditions of servomotor operation, there are different requirements for their characteristics compared to classical electric motors. The main requirements are the following: possibility to control rotation speed over wide range, linearity of mechanical and control characteristics, low inertia, adequate starting characteristics, stable rotor position according to the control signal and some others. As it is known, the most suitable motor type to be used in the role of servomotor is brushed DC motor. Such motors have the most suitable characteristics; however, their design is complex, and they have high maintenance costs, high electrical and mechanical losses, as well as insufficient safety. Brush-collector unit in its construction generally causes the described disadvantages of brushed DC motors [1]-[3].

The brushless synchronous electrical motors (synchronous permanent magnet motors and synchronous reluctance motors) are considered a good alternative to brushed motors due to their high safety level and other advantages [4]-[10].

Synchronous permanent magnet motors have such disadvantages as a high 
cost of permanent magnets and high electromagnetic torque ripple. High electromagnetic torque ripple of such motors results from the cogging torque due to the interaction between the permanent magnets of the rotor and the stator slots. In comparison with synchronous permanent magnet motors, synchronous reluctance motors have low value of the electromagnetic power (torque) per unit volume. Moreover, synchronous reluctance motors also have high electromagnetic torque ripple that, in that case, is the result of the rotor magnetic asymmetry.

Synchronous reluctance motors have neither winding of excitation nor permanent magnets, which is why they are safer and cheaper in comparison with other types of electric motor. The operation principle of synchronous reluctance motor is based on a deep variation in the magnetic flux due to different reluctance on its way.

The aim of the paper is to study features and application possibilities of synchronous electronically commutated motors in servomotor operation modes.

\section{CONTROL FEATURES OF DIRECT CURRENT AND ALTERNATING CURRENT SERVOMOTORS}

Direct current (DC) and alternating current (AC) motors are widely used in servomotor operation modes. From the perspective of control method, DC servomotors can be divided into servomotors with anchor control and that with pole control. Servomotors with anchor control have constant excitation current value, while control possibility is based on change of anchor winding voltage $U_{c}$ value and direction. In this case, shapes of characteristics $T=f\left(U_{c}\right)$ and $\omega=f\left(U_{c}\right)$ are linear. Since excitation current is constant, in some cases excitation winding can be replaced with permanent magnets.

Anchor winding of servomotors with pole control is supplied with constant voltage value, so the excitation winding - with control voltage $U_{c}$. This requires less control power; however, characteristics $\omega=f\left(U_{c}\right)$ are no longer linear. That is why anchor control is often used. The use of hollow non-magnetic or slotless anchor with pressed winding in DC servomotor increases possibility of stabile high-speed control.

Of all AC servomotors, single-phase induction motors are used more often. Control of single-phase induction servomotors is implemented by three methods. The first method is amplitude control. In this case, control winding is supplied by voltage with variable amplitude value and shifted in phase by $90^{\circ}$ relative to excitation voltage. The second method is phase control, where control winding is powered by voltage with constant amplitude. In this case, servomotor is controlled by changing the phase of that voltage. The third method is based on amplitude-phase control. In this case, both control voltage amplitude and its phase compared to excitation voltage are variable values.

Phase shift between current in starter winding and current in main winding is acquired by connecting starter winding in series with active or reactive resistance. The maximum value of starting torque is achieved by connecting starter winding in series with capacitor. However, since capacitor has considerable mass and volume, it negatively affects the use of servomotor with the control method. 
Induction servomotors can be designed using the following rotor constructions: 1) squirrel cage rotor; 2) hollow non-magnetic rotor and 3) hollow ferromagnetic rotor. Design of single-phase servomotors with squirrel cage rotor is similar to a three-phase motor. The main single-phase winding of such an induction motor is placed in stator slots, while rotor is the same as squirrel cage rotor of a three-phase induction motor.

Servomotor with hollow non-magnetic rotor is designed with both inner and outer stators and rotor that is placed between them. Rotor of such a motor is designed as a hollow cylinder with thin walls and made of aluminum alloy. Servomotor with hollow ferromagnetic rotor has no inner stator because its rotor can conduct magnetic flux itself.

Servomotors with a hollow non-magnetic rotor have low mechanical inertia and thus have fast control reaction. However, a non-magnetic gap between inner and outer rotor is quite high, which leads to a decrease in efficiency and power coefficient as well as to an increase in mass and volume.

Single-phase induction motors have poor technical characteristics: significantly lower efficiency and power factor, lower overload ability, higher price compared to three-phase induction motors of the same power.

In order to ensure stable position according to the control signal, induction servomotors can be made using rotor with high active resistance, which leads to a further decrease in efficiency of the motor. Moreover, characteristics of induction servomotors are not linear.

Considering all problems mentioned above, it is important to study possibilities and features of the operation of synchronous electronically commutated motors in servomotor modes.

\section{CONTROL OF ELECTRONICALLY COMMUTATED SYNCHRONOUS SERVOMOTORS}

Synchronous permanent magnet motors and synchronous reluctance motors with electronic commutation are the objects of the present research. In general, rotation speed of these motors can be controlled by changing supply voltage for armature windings, which is somewhat similar to amplitude-control method of single-phase induction motors or armature control method of brushed DC motors. This task can also be achieved by changing angle $\theta$ (angle between vectors of the supply voltage and non-load electromotive force) or angle $\varepsilon$ (angle between rotor direct axis and armature magnetomotive force axis).

The main electromagnetic parameters of brushless synchronous electronically commutated motors can be calculated using equations given in the present paper.

If the synchronous permanent magnet motor operates with control of angle $\theta$, all basic electromagnetic parameters can be obtained from the following equations:

$$
I_{1}=\sqrt{\frac{U^{2}-2 U I_{2} \omega L \cos \theta+\omega^{2} I_{2}^{2} L^{2}}{r_{1}^{2}+\sigma^{2} \omega^{2} L^{2}}},
$$




$$
\begin{aligned}
& T=\frac{m p I_{2} L}{r_{1}^{2}+\sigma^{2} \omega^{2} L^{2}}\left[U\left(\sigma \omega L \sin \theta+r_{1} \cos \theta\right)-I_{2} \omega L r_{1}\right], \\
& P_{e m}=m I_{2} \omega L\left[\frac{U\left(\sigma \omega L \sin \theta+r_{1} \cos \theta\right)-I_{2} \omega L r_{1}}{r_{1}^{2}+\sigma^{2} \omega^{2} L^{2}}\right], \\
& t q \varphi=\frac{\omega L\left[\sigma U-I_{2}\left(\sigma \omega L \cos \theta+r_{1} \sin \theta\right)\right]}{U r_{1}+I_{2} \omega L\left(\sigma \omega L \sin \theta-r_{1} \cos \theta\right)},
\end{aligned}
$$

and with control of angle $\varepsilon$ all basic electromagnetic parameters can be obtained from the following equations:

$$
\begin{aligned}
& I_{1}=\frac{-I_{2} \omega L\left(\sigma \omega L \cos \varepsilon+r_{1} \sin \varepsilon\right)}{r_{1}^{2}+\sigma^{2} \omega^{2} L^{2}}+ \\
& +\frac{\sqrt{I_{2}^{2} \omega^{2} L^{2}\left(r_{1} \sin \varepsilon+\sigma \omega L \cos \varepsilon\right)^{2}+\left(r_{1}^{2}+\sigma^{2} \omega^{2} L^{2}\right)\left(U^{2}-I_{2}^{2} \omega^{2} L^{2}\right)}}{r_{1}^{2}+\sigma^{2} \omega^{2} L^{2}}, \\
& T=m p L I_{1} I_{2} \sin \varepsilon \\
& P_{e m}=m \omega L I_{1} I_{2} \sin \varepsilon \\
& \operatorname{tg} \varphi=\frac{\omega L\left(\sigma I_{1}+I_{2} \cos \varepsilon\right)}{I_{2} \omega L \sin \varepsilon+I_{1} r_{1}}
\end{aligned}
$$

where $\omega$ is the armature current angular frequency proportional to the rotor rotational speed $n=\frac{\omega}{2 \pi p}$;

$p \quad$ is the number of pole pairs;

$m \quad$ is the number of phases;

$L \quad$ is the inductance corresponding to the flux of armature reaction;

$r_{1} \quad$ is the active resistance of the armature winding;

$I_{2}$ is the current of the excitation winding reduced to the armature winding;

$I_{1} \quad$ is the current of the armature winding;

$T \quad$ is the electromagnetic torque of the motor;

$P_{e m} \quad$ is the electromagnetic power of the motor;

$U \quad$ is the phase voltage applied to the armature winding;

$\varphi \quad$ is the phase shift angle between the armature voltage and current;

$\sigma \quad$ is the dissipation factor of the armature winding.

Equations (1)-(8) have been obtained for a synchronous machine with nonsalient poles. As known, the motors with permanent magnets have no excitation winding. Therefore, excitation current $I_{2}$ in these equations is calculated as equivalent, i.e., providing the same magnetic flux in the motor as obtained owing to perma- 
nent magnets. The methodology for determination of this equivalent current for the synchronous permanent-magnet motor is given in [11].

If the synchronous reluctance motor operates with control of angle $\theta$, the following equations describe motor electromagnetic parameters:

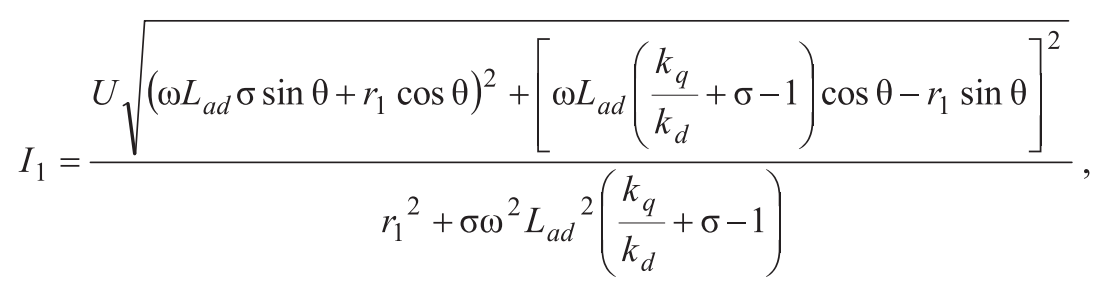

$$
\begin{aligned}
& T=m p L_{a d} U_{1}^{2} \times \\
& \times \frac{\left[\omega L_{a d}\left(\frac{k_{q}}{k_{d}}+\sigma-1\right) \cos \theta-r_{1} \sin \theta\right]\left(\sigma \omega L_{a d} \sin \theta+r_{1} \cos \theta\right)\left(1-\frac{k_{q}}{k_{d}}\right)}{\left[r_{1}^{2}+\sigma \omega^{2} L_{a d}^{2}\left(\frac{k_{q}}{k_{d}}+\sigma-1\right)\right]^{2}} \\
& P_{e m}=\frac{m \omega L_{a d} U^{2}\left[\omega L_{a d}\left(\frac{k_{q}}{k_{d}}+\sigma-1\right) \cos \theta-r_{1} \sin \theta\right]\left(\sigma \omega L_{a d} \sin \theta+r_{1} \cos \theta\right)\left(1-\frac{k_{q}}{k_{d}}\right)}{\left[r_{1}^{2}+\sigma \omega^{2} L_{a d}^{2}\left(\frac{k_{q}}{k_{d}}+\sigma-1\right)\right]^{2}}, \\
& \operatorname{tg} \varphi=\frac{\omega L_{a d}\left[\sigma \sin ^{2} \theta+\left(\frac{k_{q}}{k_{d}}+\sigma-1\right) \cos ^{2} \theta\right]}{r_{1}+\frac{1}{2} \omega L_{a d}\left(1-\frac{k_{q}}{k_{d}}\right) \sin 2 \theta}
\end{aligned}
$$

and with control of angle $\varepsilon$, the following equations describe motor electromagnetic parameters:

$$
\begin{aligned}
& I_{1}=\frac{U}{\sqrt{\left(\omega L_{a d} \sigma \cos \varepsilon+r_{1} \sin \varepsilon\right)^{2}+\left[\omega L_{a d}\left(\sigma-1+\frac{k_{q}}{k_{d}}\right) \sin \varepsilon-r_{1} \cos \varepsilon\right]^{2}}}, \\
& T=\frac{1}{2} m p L_{a d} I_{1}^{2}\left(1-\frac{k_{q}}{k_{d}}\right) \sin 2 \varepsilon,
\end{aligned}
$$




$$
\begin{aligned}
& P_{e m}= \frac{1}{2} m \omega L_{a d} I_{1}^{2}\left(1-\frac{k_{q}}{k_{d}}\right) \sin 2 \varepsilon, \\
& \operatorname{tg} \varphi=\frac{\omega L_{a d}\left(\cos ^{2} \varepsilon+\frac{k_{q}}{k_{d}} \sin ^{2} \varepsilon+\sigma-1\right)}{r_{1}+\frac{1}{2} \omega L_{a d}\left(1-\frac{k_{q}}{k_{d}}\right) \sin 2 \varepsilon} .
\end{aligned}
$$

where $L_{a d}$ is the inductance that corresponds to the armature magnetic flux along the direct axis.

\section{MECHANICAL AND CONTROL CHARACTERISTICS}

Equations described in Section 3 allow calculating mechanical and control characteristics for synchronous motors and assessing their compatibility to servomotor requirements.

Figure 1 presents the calculated mechanical curves for synchronous permanent magnet motor with the following parameters: $p=2, m=3, U=92 \mathrm{~V}, L=$ $0.00061 \mathrm{H}, r_{1}=0.25 \Omega, \sigma=1.04$; equivalent excitation current $I_{2}=50 \mathrm{~A}$. The case with predetermined angle $\varepsilon$ has mechanical curves with better linearity. All curves are given in relative values, where maximum value is taken as the base value.

a)

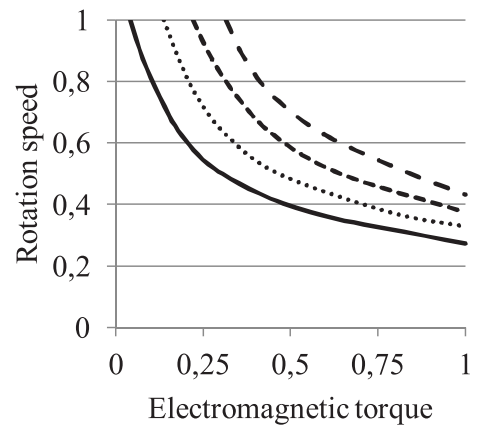

$\begin{aligned}-\theta & =5 \mathrm{deg} \quad \cdots \cdots \cdots \cdot \theta=10 \mathrm{deg} \\ ---\boldsymbol{\theta} \theta & =15 \mathrm{deg} \quad---\theta=20 \mathrm{deg}\end{aligned}$ b)
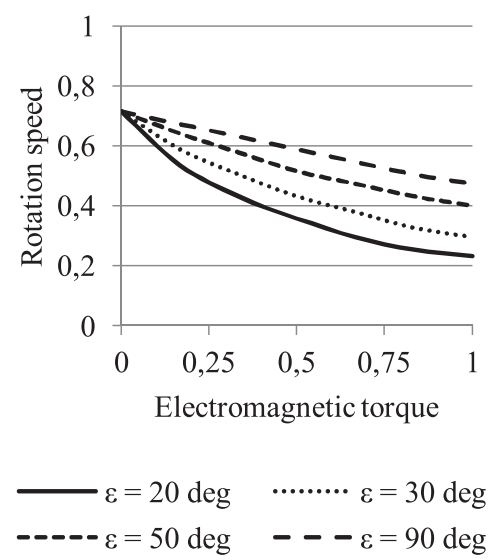

Fig. 1. Mechanical curves for permanent magnet synchronous motor with controlled angle $\theta$ (a) and controlled angle $\varepsilon(b)$.

In the case of synchronous reluctance motor, the both mechanical curves with controlled angles $\theta$ and $\varepsilon$ have similar form. As an example, mechanical curves with controlled angle $\varepsilon$ are shown in Fig. 2. Parameters of synchronous reluctance motor are: $p=1 ; m=3 ; L_{a d}=0.32 \mathrm{H} ; r_{1}=4.98 \Omega ; \sigma=1.15 ; k_{q} / k_{d}=0.15 ; U=220 \mathrm{~V}$. 


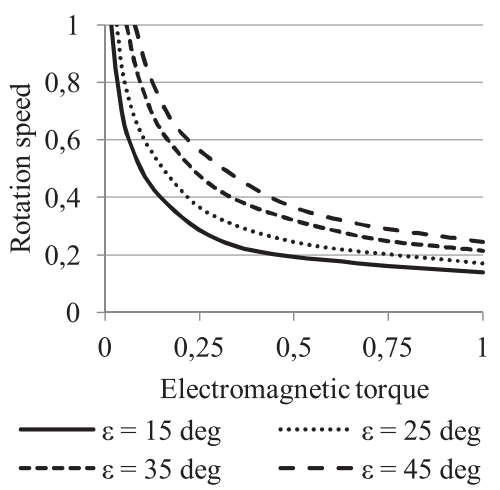

Fig. 2. Mechanical curves for synchronous reluctance motor with controlled angle $\varepsilon$.

Figure 3 demonstrates control curves for synchronous permanent magnet motor with variable supply voltage as operation mode with controlled voltage $U$, predetermined torque values and constant angles $\theta$ and $\varepsilon$. Permanent magnet motor control curves with variable supply voltage have similar form. Curve inclination angle depends on selected angle $\theta$ or $\varepsilon$ values. A similar situation arises in case with a synchronous reluctance motor. For example, control curves for a synchronous reluctance motor with variable supply voltage with predetermined torque values and constant angle $\varepsilon=45^{\circ}$ are shown in Fig. 4. Summarising the information, it is clear that the both synchronous motor types have similar control curves with variable supply voltage, which are close to linear.

a)

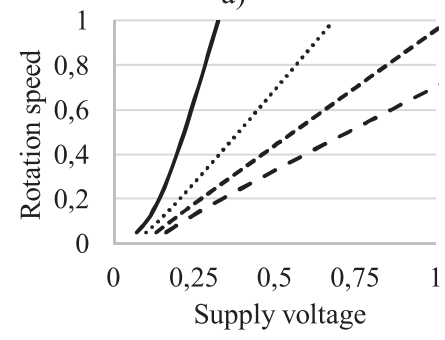

$\begin{aligned}-\mathrm{M}=1 \mathrm{~N} \cdot \mathrm{m} & \cdots \cdots \cdot \mathrm{M}=3 \mathrm{~N} \cdot \mathrm{m} \\ ----\mathrm{M}=5 \mathrm{~N} \cdot \mathrm{m} & ---\mathrm{M}=7 \mathrm{~N} \cdot \mathrm{m}\end{aligned}$ b)

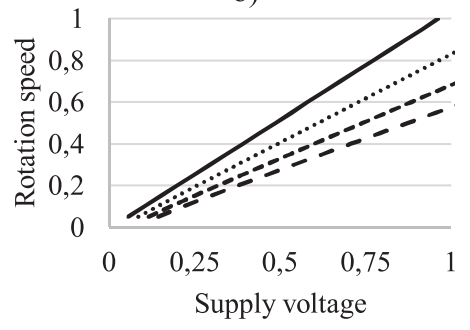

$\longrightarrow \mathrm{M}=1 \mathrm{~N} \cdot \mathrm{m} \quad \cdots \cdots \cdot \mathrm{M}=3 \mathrm{~N} \cdot \mathrm{m}$ $----M=5 \mathrm{~N} \cdot \mathrm{m} \quad---\mathrm{M}=7 \mathrm{~N} \cdot \mathrm{m}$

Fig. 3. Control curves for permanent magnet synchronous motor with variable supply voltage and constant angle $\theta=30^{\circ}$ (a) and $\varepsilon=45^{\circ}(\mathrm{b})$.
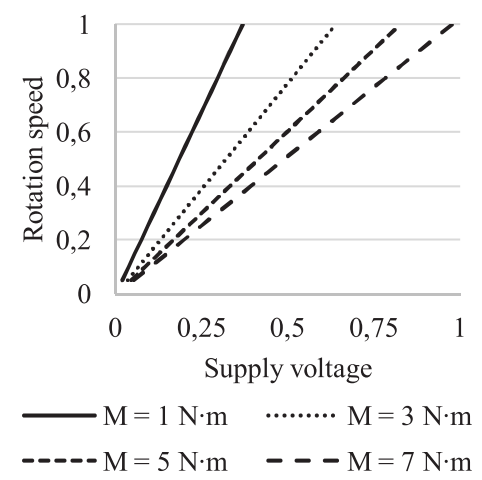

Fig. 4. Control curves for synchronous reluctance motor with variable supply voltage and constant angle $\varepsilon=45^{\circ}$. 
In order to operate the synchronous reluctance motor in servomotor modes, its rotation speed can be controlled by angle $\theta$ or $\varepsilon$, thus executing a specific phase control method. Control curves for permanent magnet synchronous motor with variable angle $\theta$ or $\varepsilon$ are shown in Fig. 5, and for synchronous reluctance motor - in Fig. 6. Results show that in the case with angle $\theta$ as a control signal, curve form is more linear than in the case with control angle $\varepsilon$.

a)

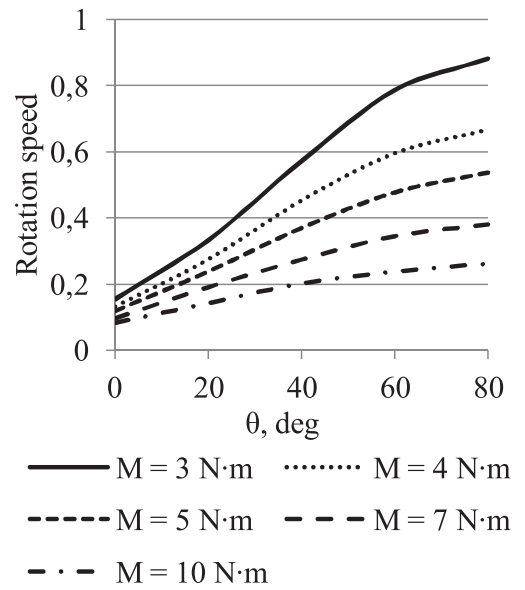

b)

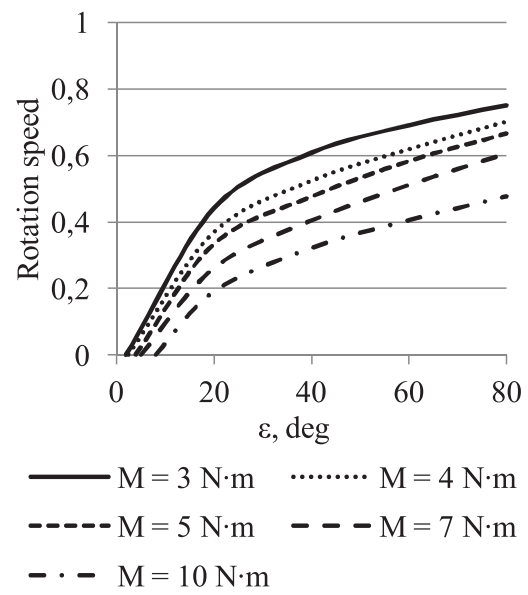

Fig. 5. Control curves $n=f(\theta)$ (a) and $n=f(\varepsilon)$ (b) for permanent magnet synchronous motor at $U=92 \mathrm{~V}$.

a)

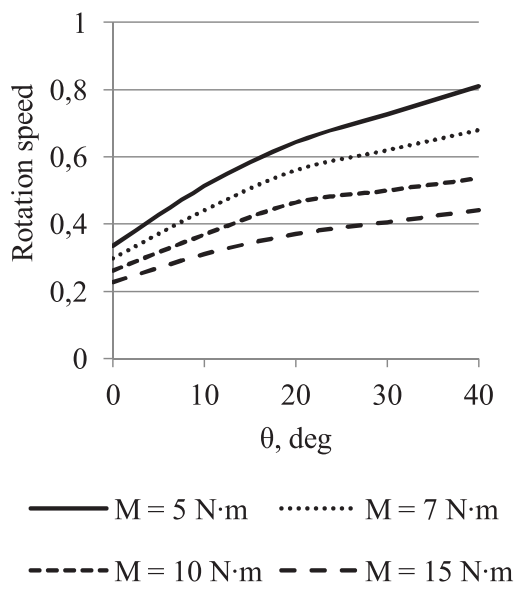

b)

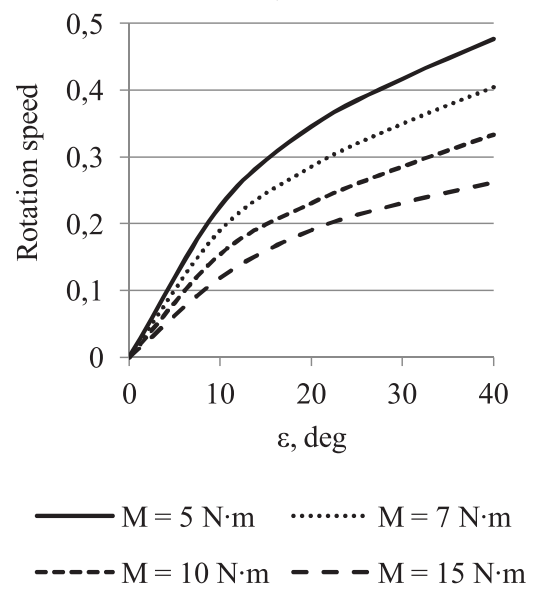

Fig. 6. Control curves $n=f(\theta)$ (a) and $n=f(\varepsilon)$ (b) for synchronous reluctance motor at $U=220 \mathrm{~V}$.

In order to prove the obtained results, theoretically calculated results, which are presented in this paper for synchronous reluctance motor, are compared with experimental results that are presented in the study [12] (Fig. 7). The experimental curve of the studied motor shows a good coincidence with the calculated curve. 


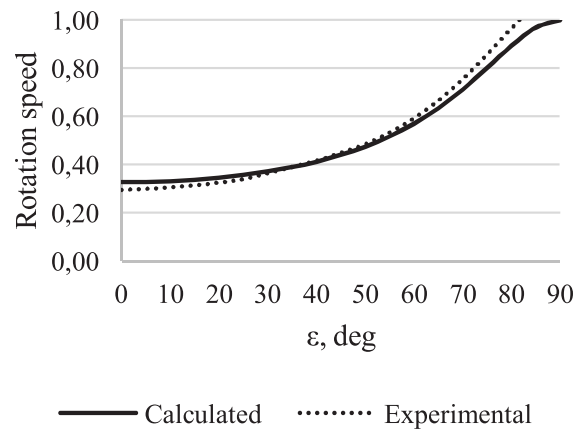

Fig. 7. Control curves for a synchronous reluctance motor.

\section{CONCLUSIONS}

Based on the results obtained, the following conclusions can be made:

1. Control of electronically commutated synchronous motors in servomotor operation modes can be achieved by the variation of angle $\theta$ (angle between vectors of the supply voltage and non-load electromotive force) or angle $\varepsilon$ (angle between rotor direct axis and armature magnetomotive force axis).

2. Mechanical characteristics of a synchronous permanent magnet motor are more linear in comparison with the corresponding characteristics of a synchronous reluctance motor.

3. Synchronous electronically commutated motors as servomotors have sufficient potential as an alternative to DC and AC servomotors.

\section{ACKNOWLEDGEMENTS}

The present research has been supported by the State Research Programme "LATENERGI".

\section{REFERENCES}

1. Hugles, A. (2006). Electric Motors and Drives. Fundamentals, Types and Applications (3rd ed.). Newnes. ISBN-13: 978-0-7506-47182.

2. Firoozian, R. (2014). Servo Motors and Industrial Control Theory (2nd ed). Springer. ISBN-13: 978-3319072746.

3. Wahyunggoro, O., \& Saad, N. (2010). Analysis and evaluation of real-time and s-domain model of a DC servomotor. In Intelligent and Advanced Systems (ICIAS), 2010 International Conference (pp. 1-5). DOI: 10.1109/ICIAS.2010.5716206.

4. Levin, N., Kamolins, E., \& Vitolina, S. (2014). Brushless Electric Machines. Riga: RTU (in Latvian). 
5. Dote, Y., \& Kinoshita, S. (1990). Brushless Servomotors Fundamentals and Applications. Oxford: Clarendon Press.

6. Zorlu, S., Senol, I., \& Bakan, A.F. (2006). Vector control of an AC brushless servomotor using a custom-designed motion control card. In 2006 IEEE International Symposium on Industrial Electronics (vol. 3, pp. 2516-2521). DOI: 10.1109/ISIE.2006.295968.

7. Terentiev, S.A., Povernov, E.S., \& Sypin, E.V. (2004). The direct-current servomotor control system. In Proceedings of the 5th Annual International Siberian Workshop on Electron Devices and Materials (pp. 184-186). DOI: 10.1109/PESC.2004.241338.

8. Pillay, P., \& Krishnan, R. (1991). Application characteristics of permanent magnet synchronous and brushless DC motors for servo drives. IEEE Transactions on Industry Applications, 27(5), 986-996. DOI: 10.1109/28.90357.

9. Dirba, J., Lavrinovicha, L., \& Dobriyan, R. (2015). The prospects of synchronous reluctance motors usage in low power electrical devices. Latv. J.Phys. Tech.Sci., 52(2), 40-48. DOI: 10.1515/lpts-2015-0010.

10. Lavrinovicha, L., \& Dirba, J. (2015). Brushless Synchronous Motors with External Rotor. Riga: RTU (in Latvian).

11. Dirba, J., Roldugina, N., \& Pugačevs, V. (2001). Methodology of permanent magnet brushless DC motor calculation and optimization. Scientific Proceedings of Riga Technical University: Power and Electrical Engineering (Ser. 4, Vol 4, pp. 48-53) (in Latvian).

12. Dirba, J. (1997). Special Operation Modes of Synchronous Machines. Riga: RTU (in Latvian).

\title{
SINHRONO VENTILLZINĒJU DARBA İPATNĪBAS SERVODZINĒJU REŽİMOS
}

\author{
J. Dirba, L. Lavrinoviča, R. Dobrijans
}

Kopsavilkums

Aplūkotas sinhrono ventiḷdzinēju ar pastāvīgajiem magnētiem un sinhrono reaktīvo ventiḷdzinēju iespējas un darbības īpatnības servodzinēju režīmos. Aprēķinātas to mehāniskās un regulēšanas raksturlīknes, kas ir tuvas lineārām. Piedāvāts minēto dzinēju vadību īstenot līdzịgi kā asinhroniem servodzinējiem ar fāžu vadību, t. i. mainot leņķi $\theta$ starp dzinēja pret EDS un barošanas sprieguma vektoriem vai leņķi $\varepsilon$ starp enkura magnetodzinējspēka asi un rotora garenasi. Parādīts, ka sinhronos ventiḷdzinējus daudzos gadījumos var izmantot kā servodzinējus.

10.05.2016. 